\title{
Growing Communities in a Garden Undone: Worldly Justice, Withinness and Women
}

\author{
Simone Miranda Blom ${ }^{1, *}$ and Sarah Crinall ${ }^{2, *}$ (D) \\ 1 School of Education, Southern Cross University, Lismore NSW 2480, Australia \\ 2 Centre for Educational Research, Western Sydney University, Sydney NSW 2747, Australia \\ * Correspondence: simone.blom@scu.edu.au (S.M.B.); s.crinall@westernsydney.edu.au (S.C.)
}

Received: 27 September 2019; Accepted: 16 December 2019; Published: 31 March 2020

\begin{abstract}
Where communities are ecological and humans are nature, ways of reimagining and regenerating communities as human and more, offer a timely response to the call of the Anthropocene for worldly justice. We, the authors, as women and mothers, look into time, place and space, harvesting our 'becoming (undone)' for the reader, seeded in the botanical world. Creeping and whispering, still and subtle, plant species are ever present in our survival yet often go unnamed and unnoticed, and to date are under-represented in multi-species becoming research. Via Foucault's shining light upon power, we muse with Barad, Haraway and Grosz-how does growing (with) plant-life, amongst what is 'said' and 'unsaid', matter (to) the world as it turns? We have been returned to the same sediment after a decade: Our bowed-together life revived in the childhood-motherhood-nature community entanglements of the Anthropocene. Now, this paper, waters plant-human relationalities living beyond the traditional parochial human-to-human role. We accept our humanness in its onerousness and ownership but look to the leaf litter to reacquaint with our multispecies lives in a garden that has, at times, been sacrificed and lost. Our contribution is chlorophyllic. New ideas enfold and energise what constitutes a community. As women woven with botanica and academia, where mothering is a collaboration rather than a raising, we invite the reader to journey with us into the worldly, life-giving relations that garden a community undone.
\end{abstract}

Keywords: community; more-than-human; mothering; intra-action; bodyplaceblogging; becoming other; withinness

\section{The Entrance}

These blooming word-beds are our timely response to the call of the Anthropocene (Crutzen and Stroermer 2000); to aerate the surface of bodies, both speaking and unspeaking. Where dominant, capitalist modes have been commodifying the non-human world for human utility, we wander through this garden, now, with feminist new materialisms, witnessing and participating in sowing slow disruptions in traditional ways of knowing and relating. As we walk, we wonder what counts as a meaningful world, while we listen, touch and attune to communities living beyond Homo sapiens sapiens-centred limits for worldly justice.

This entrance serves as a preface and you will notice as you walk through the garden that many of the titles and words have been playfully adjusted as we weed, dig, tend and mulch this garden — the words that form this paper. In responding to the Genealogy special edition call to re-imagine community, family, motherhood and childhood in the Anthropocene, we reconceptualise with 'community', drawing theory through co-compos(t)ed, playful 'blog posts' of text and images that appear like texto-visual short poems. What is presented here is research from an emerging post-qualitative tradition. Through writing this paper, we have given ourselves permission to let go of the traditional research paradigm 
from which we were originally sown, and we welcome you to do the same. We offer here a provocation where truths are not generalisable nor summerisable.

We kept a bodyplaceblog together (Crinall 2016). After co-journalling a conversation with body and place awareness (co-bodyplaceblogging) for a year, we dug through our composted works. Certain garden features drew our attention and a series of inhabitants-flora and fauna and more-encountered by us alike have woven through philosopher's musings bringing a new kind of sense-making. With Michel Foucault, Karen Barad, Elizabeth Grosz, Donna Haraway and others, learning and writing together formed our knowledge production process. Challenging ourselves to think newly and differently with community, we lateralise matter onto a floor (see Deleuze and Guattari 1994), grounding the search for alternative ways to be with and in a world anxious with disconnection, species loss and life-threatening habitat alteration.

So, we invite you to get messy with us in the garden. We have some seeds here that you may take with you. They might sprout knowledge from your body in specific spaces, places and time while you wander paths we see, and do not see. From here, you could find that your own research garden starts to grow. Enjoy your journey through our garden.

Pressing and Unfurling

‘To what can feminist theory aspire that open us up to the embrace of an unknown and open ended future, that bring into existence new kinds of beings, new kinds of subjects and new relations to objects'

(Grosz 2011, p. 75)?

Feminist new materialisms sow slow disruptions in traditional ways of knowing and relating, and fertile becomings and unbecomings are seeded. With feminist community openings, from slow to sow, the ' 1 ' is leaving, sprouting forth growings of 1 (eaf), l(ight) and l(ife) through playful intra-actions on our shared body-space blog with place.

slow peas in teeth

We

diffract

Rainbow

to see what emerges next

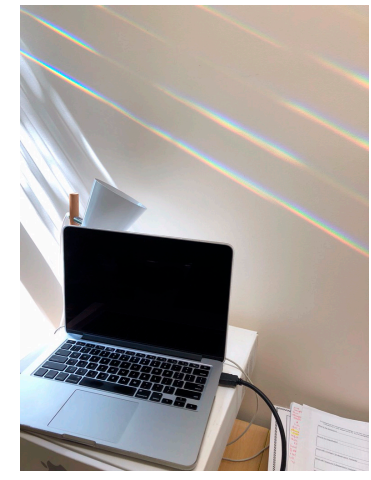

sunraydance grappling 
We wheel our composted lives through the entrance into a shared blogged garden. We are marvelling at our meeting again in the entanglements of the Anthropocene after a decade of co-fossicking similarly for sustainability apart. Before we encountered each other in academia, we were co-sunraydance grappling with Barad's $(2007,2012)$ diffraction and onto-epistemology of intra-action. Becoming over knowing, though apart, we had simultaneously learned to play in a realm beyond Cartesian ontology, which knows matter to 'interact' and combine two separate entities into one through connection (Barad 2007, 2010, 2012). 'Intra-acting' with the world we came to understand matter as emerging out of an entanglement with agency as spaces, times and bodies (human and other) always, already enfolding back into the entanglement, diffractively, and potentially 'other'.

Now, in the garden together, Grosz (2011) is watering our feminism in academic writing with philosophy and art. As she hydrates becomings that undo our knowable and pre-defined selves, Haraway's (2016) digging stick also shifts us from posthumanism's decentring of the human, into humusness. Here motherhood and childhoods are also naturehoods, sustaining and becoming childhoodnatures (e.g., Blom 2018; Crinall 2019; Crinall and Vladimirova 2020; Cutter-Mackenzie-Knowles et al. 2019; Vladimirova and Rautio 2018). These feminist new material tendings offer fertile earth for concepts of childhood, motherhood, family and community to breathe out from under the more dominant 'generalising, universalizing concepts that reach across broad stretches of time and space' (Foucault 1978 as cited in Osgood and Sterling Henwood, pers. comm), and with them we breathe.

Twenty years before writing this paper together, we were calling each other names inspired by botanical species as students of the biological sciences. As Cinnamonii (Cin) and Epacris impressa (Press), our mutual love of botany brought us to make precious oceanic algal (seaweed) pressings.

Algal pressing from my 21st

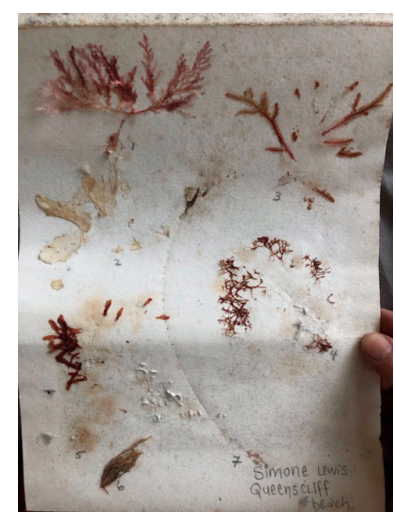

Photosynthesisising

Photo-cin-thesisising

Photo-cin-press-is

Press-cin-thesis

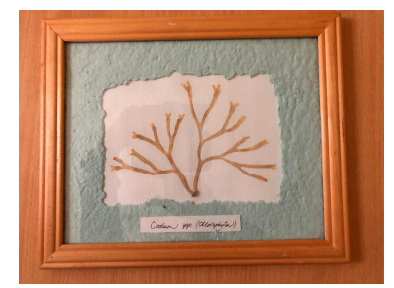

Algal pressing from my 21 st

We gifted these to each other and then fell out of touch. We found, in each other's hands, the pressings still remained, two decades on, algal gifts, algae adrift. Gifts adrift, they dried and curled, 
were nibbled by time, and partly preserved-like our kinship. Having found them both, during our reunion via academia we notice, they are preserved as salty algae on paper-are they also press-cin our 'unrecognisable unselves' (Grosz 2011) on paper-much like we do here, in this paper ${ }^{1}$ ?

Algal photosynthesis turns light energy into something storable. This co-blog post above accepts us as energetic bodies (as press-cin-thesis), and emanates us into a musing, how does growing (with) plant-life, amongst what is 'said' and 'unsaid', matter (to) the world as it turns?

As light and matter, we continue on.

Somerville (1999) Body/Landscape Journals asserted a body's right to know place (see also Grosz 1994). It comes to us that a body might also like to grow there. With post-qualitative theories that beckon the body as knower, we peer into the already existing communities we live in. Known via our bodies, they are not only a human-to-human affair. As children we were raised in communities defined by their similarity. Being a part of the Victorian community, a community of artists, or a community of scientists, what if we mess with what 'being a part of' is? Where 'being' is becoming and 'a part' is also apart, 'becoming apart from the human body' alone we are shuffled (back) into an ecological community-where two or more species are receiving and contributing to life in particular processes, through proximal relations of time, space and place.

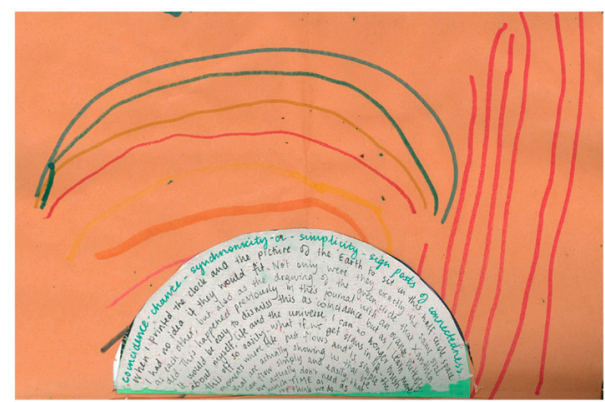

Found it in a treasure box

A page from my journal

rainbows and words on synchronicity

travelling parallel lives and worlds

synchronicity

cin-chron-I-sip-tea

now I remember sipping a blue colour caravan tea with you

cinchronicity

imagine how we could be

in relationships

if we met someone 'anew' each time we saw them again

Drawing on the power and force of materiality for childmothernaturehoods that Blom (2018) found in the treasure box travelling parallel lives and worlds, we edge closer to hearing the shifting unspeakable. Differently, lightly, darkly, lively.

\section{A note on the post-qualitative feminist call between the 'said' and 'unsaid'}

and today I am (re)reading Barad (2007 page 63, meeting the universe halfway))

1 This article was written as a collaboration. The order of authors names is based on the writer who encountered the publication invitation as first author. 


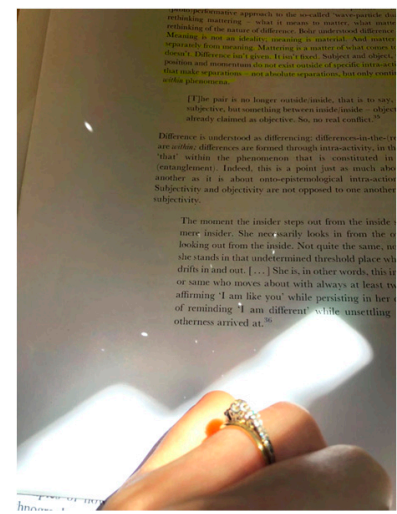

talking about Foucault

I am grappling with the difference

between discourse and discursivity

and rainbow but

now am wondering about the difference between discursive and nondiscursive practices

or perhaps the relationship between the Foucault described 'said and unsaid' that

Foucault left

Unsaid.

Gazing up from the grass we pause between what is 'said' and 'unsaid,' in the Anthropocene (Crutzen and Stroermer 2000), to see kin sown in Haraway's (2016) hydrating Chthulucene. The 'said' can be what is named culturally meaningful (Barad 2007), and the 'unsaid' might be the unspeaking and unspeakable (Grosz 2011). Life here emerges out of difference, 'a process that produces itself' (Grosz 2011, p. 92). The Chthulucene is offered in place of the Anthropocene, and is named after a Chthulu spider's non-linearising web-a present-minded 'timeplace' intimate with the cloudy troubles of living where embodied thinking radiates (Haraway 2016). Here, communities are ecological and humans are nature (Blom 2018; Dickinson 2013; Osborn et al. 2019). We wonder, what if we listen in to the many, various 'bodies' ${ }^{2}$ that are already reimagining and regenerating (for) communities? We want to experience them, revel in their difference, their more-than-just-humanness, as they energise into 'new kinds of beings, new kinds of subjects and new relations to objects' (Grosz 2011, p. 75).

With adventurous thoughts and sensing senses, feminist philosopher contemporaries such as Barad, Haraway and Grosz work with what Foucault left unsaid. We notice, as they sow and harvest multispecies lives (Haraway 2016); making, unmaking, doing and undoing identity-classification into difference as philosophy (Grosz 2011; Barad 2014), matter matters in relation — by what we tend in a moment and over a life. Life here is also various vessels that may 'be' and not 'be' simultaneously; bonded inextricably, meaning and bodies also break apart. As described by Barad (2007) as 'cutting together-apart' (p. 173; see also Barad 2014, p. 168), here, the universe's light and dark bodies are ever shaking out and folding in, ever-diffracting off what is.

Where Foucault touched on the materiality of bodies as central to defining what counts as a meaningful statement (Barad 2007, p. 63), we want to aerate this surface of bodies, both speaking and unspeaking in wonder: What counts as a meaningful world? Through this article we listen, touch and attune to communities living beyond the Homo sapien-centred limits of the Chthulu-Anthro-planta-scene by co-journalling with plants and more about worldly motherchildnaturehoods and sustenance. Come and play in the garden as we do, (re)turning to communities, undone.

2 See Affrica Taylor (2017) for example for work on multi-species lives and common worlds. 


\section{Part One: On light}

\section{Botanical Attunements}

\section{Mulching}

A short share with blog today about the winter greens

captivating.

They lay across the landscape

They bound out and up at me

from places.

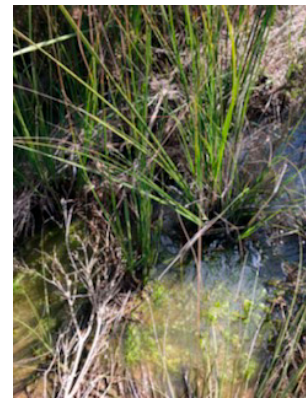

The first green to hold my hand was the grass budding out of the road

Our shared blog,

As in our cothinking threads th(inking)reading together apart

Both said and unsaid

It captures our bodies thinking

A body thinking

But it is other to cognitive rational knowing.

The unsaid speaking bodies

Our co-journal of body and place (and viscera, lignin, breathing, bodily tissue, algae, photoreception, green and on ... ) is made of blog posts just like this one. We choose to begin with this one, laid with mulch on top. Beginning at the surface, we note blogging, itself, is breaking the surface tension on post-qualitative research (see Crinall 2019). This post embeds our writing along cothinking threads, under the mulch that lays across winter greens and budding grass. Yes, the shared blog, is holding our bodies thinking, amongst the grass, and is budding something.

Perhaps, this, our first blog post, captures our bodies thinking as an entrance itself? As we follow co-thinking threads along a commonly travelled road, through research into botanical attunement we experience its flow over our bodies thinking. We notice something is mulching the unsaid speaking bodies budding into becoming. We take a moment to notice them where botanica seems largely under-represented in posthuman research. What are these? New entities? Immaterials living in the blogjournal? Blurrings of body-and-place; person-to-person: animal-and-plant; and wave-and-particle? As we dig it feels a Chthulucenian garden.

\section{Let's Stroll Together}

on Saturday

i learnt a dance

where we aligned like gemini sisters

on Sunday 
i went for a walk

my friend commented on how part of the tree

had lost it's leaves

$i$ said it is actually two

being as one

i'd noticed that before

but now $i$ see the trees in their dance too

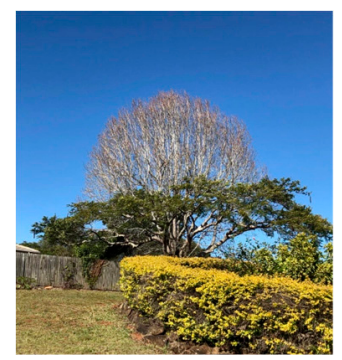

While strolling, our shared blog posts are also dancing. Land plants have an ever present eukaryotic power in our world survival and this post frames them so. We cannot help but stop to notice. Their silent dance together holds one as two and two as one. Through the post, these trees shade, feed, shy away from, mimic, surprise and pause (with) us?

it seems like i-dentifying

with the $i$

keeps out the

other

the word (i-n-divi-duality)

In-divide

Perpetuates the divided duality of

one-from-other.

I gathered these pieces of rhodophyta after sitting on a red rock on my walk this morning

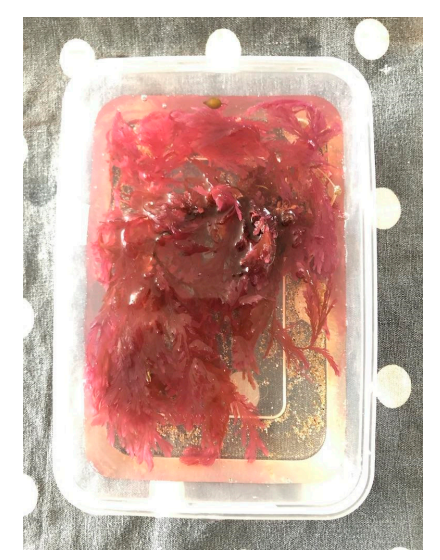

The pool of red algae laid on the paper 


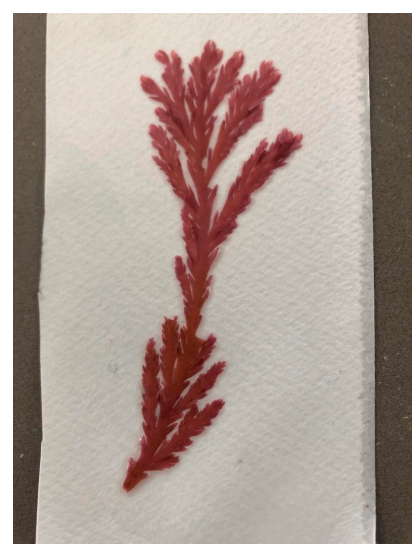

Waving and washing and then as the paper rose

It pressed against the wet algae

lay a cloth napkin over it

wrapped it in my favourite dotted tea towel

and slid it between a pile of books

"Becoming undone" and "dinosaurs"

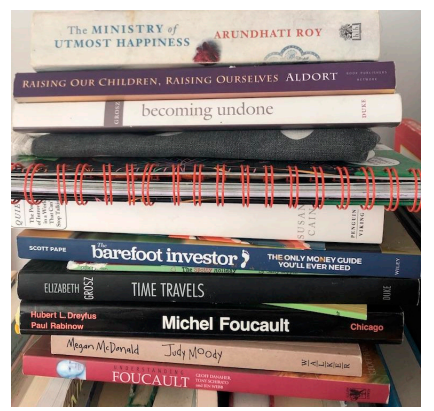

People will think the seaweed is a book

With red algae waving, what is, is becoming undone. Above, I shifts to in and, with the beauty of this algae, is preserved here. These words displayed above, we notice, are like algae, piled quietly on the sand, asking us to rethink the accepted 'I'. Somerville (2015) looks to the 'problem of writing the post-human ' $\mathrm{I}$ ' in educational research' (n.p). and offers co-blogging as one way to be with the duality, to be in-divide and indivisible. That people may think the seaweed is a book, draws our attention here, to one entity also being another.

\section{Love Litter and Leaf Letters}

This viscera-backyard blog, has inoculated its own leaf-letter diffraction:

Dear 100 yo Acorn tree 


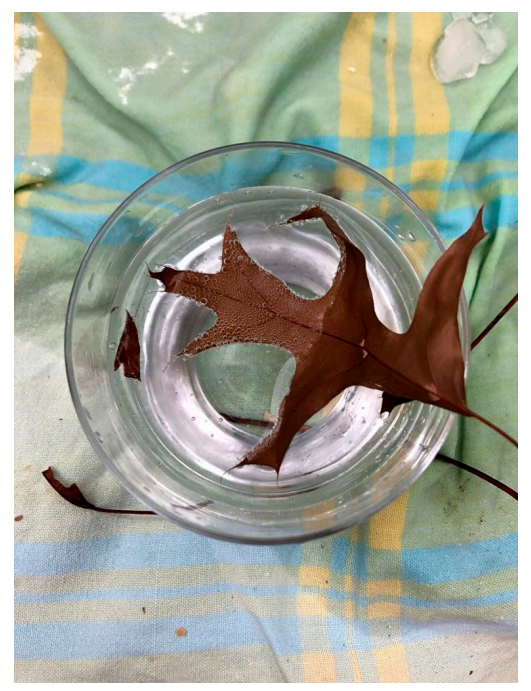

At home in my back yard you stand And birds visit you all day I see Today we made patterns with your acorns and leaves Doublcorns Tinycorns Hatted and hatless corns reveal themselves, acorn tree And you watched while we discovered you Looked Collected Aged and lay under youYou watched me grow up acorn tree And now my children are beneath your green red two tone wings A raven has just landed Black and stealth after the rustle of her feet securing herself upon your tendrils trunkEdie has returned after asking me to lay down under you and waitraven calls Arrr arrrrr arrrr arrrr Edie has something to say Meeeeeeerrrr errrrr To the raven Who still mostly silently sits.

These love litter and leaf letters from our co-body space blog were pasted here, and fell this way. They are a pile of fun and in them we lie. There are letters in the blog creating unexpected allies: a spinach seedling sent an email to a research lab warning that the toxic levels of the water in the surrounding earth had risen (see Trafton 2016); elsewhere, it is mentioned that 'heritage-listed' trees in a park and garden in Melbourne received emailed love letters of body and place, chloroplast and bark (see Burin 2018.); we also shared that the ocelli or primitive eyes of the vine Boquila trifoliolata, make out the details of shapes in the landscape and individual plants alter their bodies, in mimicry, blurring into being as other plants, to which they bind themselves for survival (Gianoli and Carrasco-Urra 2014).

These back and forth letters gathering as dry-autumn mulch might be noticed for activating warmth. We accrue an intimacy and power of both love for, and a desire to help other life to survive as we tend it, growing our knowing and proximity. For Barad (2007), spacetimematter (girthgrowthtissue), becomes out of what we give attention, with there being no separate material. These reverberating letters on plant-human entanglements wrap lively membranes, for a moment, around viscera of foliage and fingertips. Looking over to Haraway (2016, see chapter 1), together we wonder, is this 'inoculating' (p. 11) of multi-species the food, or 'humus', needed for the 'well-being of women and their people' (p. 6), 'making kin not babies', as well as for, a living Terra?

Live

Love

Lieove.

The 'Dear 100 yo Acorn tree' leaf letter above has been abscised from the blog. It came to lay this way. The words curiously perch together and leave trunkEdie and ravenWho. It also welcomes Leaves Doublcorns Tinycorns Hatted and hatless corns - unspeakable oddkins-of whom we, in our world, had not encountered yet.

The oddkins call:

waitraven say Meeeeeeerrrrr errrrr To

calls Arrr arrrrr arrrr arrrr Edie 
and we are listening,

\section{ever-In-touch}

and touching.

'so much happens in a touch: an infinity of others -other beings, other spaces, other timesare aroused'

Today my appointment timely after our meeting unearthed another layer of mothering imprints as scar-tissue on body. Something bubbles to the surface-like water breathed out through my stomata - the process of bodymind and I could feel the blog becoming through the experience

And now you find me reading about the healing properties of tree

Is that the energy that one plant sends another?

That flows. Can we learn a new humanness from trees?

Though trees age more slowly than humans

They have the same "time".

Scar born from not honouring nature time, the cycles of nature

Fixed on social time, pushed by others time,

A reminder to listen more closely to cycles.

The research, published in the journal Plant Physiology, reveals that plants react in various ways when patted or touched.

Took my walk phoneless yesterday

Sundews stayed with me til today

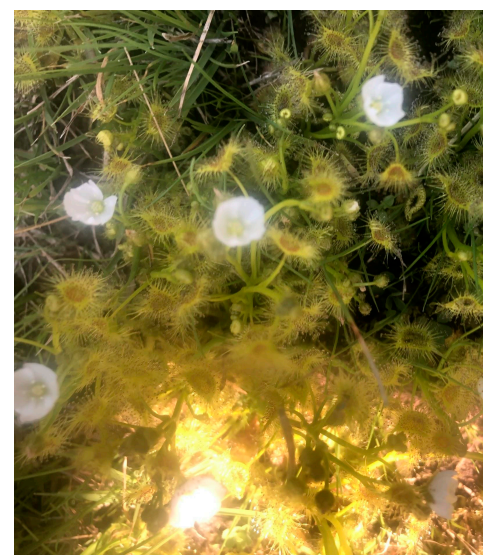

They're abundant along Lawson street swales at the moment

Looked up there movement to see if it was light-related

No

It is the kind of movement that blurs the plant-animal divide 
The beauty here is in a sundew's petals where a scar is born yet sundews stay with me. They are tentacle-like and radiate around the centre of the flower in a cycle. The centre of the flower's arms are other to their own. An ant has gone wandering, or an unlucky fly landed for nectar. The many reaching arms tune into Haraway's (2016) offering of tentacular thinking. To send out feelers in radiant fashion, may it slow us down, and decompose our scars? This co-blog post knows fast-time as dangerous to a body with a scar born of not honouring nature time. The sundews tentacles move swiftly to sustain themselves in this co-blog post. They seem most proud of their swift movement to us, but the nourishing nature of the post, as it lays down the page, is in the long lateral lines written from the heart, so nourishing to drink, worth being trapped for?

Taking our time, we experience less mourning, less loss.

No mourning of loss

I love this process with you

Healing

Regenerating

Undoing

Retreating

exposing.

Retreating back to the exchange of the algal gifts we can understand this differently.

I have a pressing dug from under the bed. This algal gift, given from you to me two decades before, is nibbled on.

Hints of the alga, Plocamium remain.

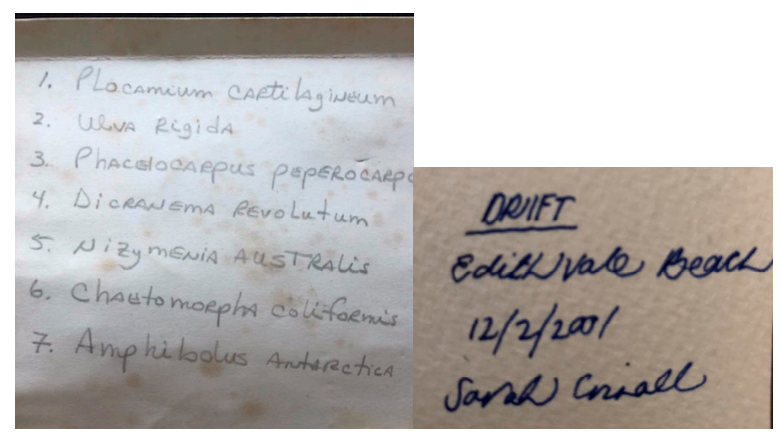

The botanical names written in grey lead indicate what the others,

invisible now, were.

What is matter and what we call touching is regenerating. Whether visible or not.

For Barad,

'When two hands touch, there is a sensuality of the flesh, an exchange of warmth, a feeling of pressure, of presence, a proximity of otherness that brings the other nearly as close as oneself. 
And if the two hands belong to one person,

might this not enliven an uncanny sense of the otherness of the self'

(Barad 2012, p. 1)

As not solely classical-human, attuning to (our) other matter makes for a new kind of flesh, doing a new kind of touching. These 'two hands belonging to the same being' may not be solely of the one Homo sapien sapiens variety. We propose, because two is also one, however, that there will be the same

$$
\begin{array}{r}
\text { 'sensuality of the flesh, } \\
\text { exchange of warmth, } \\
\text { feeling of pressure, } \\
\text { of presence' }
\end{array}
$$

(Barad 2012, p. 1)

on sunday i spoke with another sister friend about why there is this drive that overrides the voice of womanly body that is tired or hungry or not enjoying herself is it because we think as women we need to be able to do it all? do we not trust the abundance that is there constantly waiting for us when we honour our wom(b)anly body first? social impositions, baradian material discursive forces (also of deleuze \& guattarian nature as expressed through Massumi 1992) impacts on material form without giving materiality it's own agency is this agential realism?)

a walk, my friend

i went, I return

My body heading down

Moving logs of body lily pily

Alike sisters on Sunday

lily pily sister

Love seaweed sister

In this long-ago leaf letter youYou signed off as 'seaweed sister'. We say nothing more than to leave a space for the discursive forces of this post to be experienced as you read it (see Barad 2007 on material-discursivity; and also, Brown et al. 2020). A quiet pause to make space to materialise what is more uncertain, more playful and 'maybe more' for a feminine classification of what is becoming (e.g., see also Charteris et al. 2019; MacLure 2013; Ulmer 2017; St. Pierre 2014).

For Rautio (2013, p. 455), 'being nature is to construe yourself to a universe that articulates through you and extends beyond you'. Often when we do not look, the universe finds us, when we are open to hearing its voice.

... night day moon sun traversing

Infinitely and expandingly like the universe

this sparkling light ray passing my gaze,

प्र

You are my breath

In out in out

Is this the universe speaking to the 'light rays, tree and apple'? 
you are my breath. In out in out.

Returns me to the simplicity of breathing

Of being with

Other

$B(r)$ e(ath)ing

I like that being is in breathing

Oh yes! Here it is: breathing being

Yes. Ancient

I have mentioned nothing but she is asking me to call her 'Plant'

Promiscuous feminist research no longer seeks to stay within the sole bounds of positivist rationalism, making blurry what 'is' with promiscuities (see special issue on feminist promiscuousness via MacLure 2013). 'Who is' continues to dance.

I count your rings to know your age

Attuned

sun and daughter-sun speckle light through trees

shine brightly

Yesterday, sun peeked under bathroom door

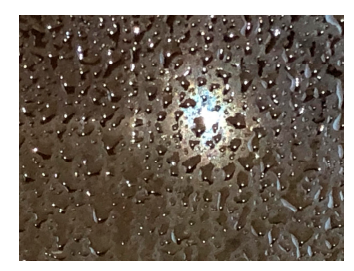

refracted through shower screen droplets and circular rainbows

oh these circular rainbow beads water my face!

As you spoke, sparkles of light danced across the roof of your car

then,

the light reflected off my engagement ring and sparkled across my desk.

dancing light sparkles

a timely reminder

for life

for writing

for being

As the sea sparkles

So did you

A calm sea floating in my vision

Now we have chopped you down light pours in

Still 
Studies of 'nature' and childhood, motherhood, family and community (e.g., Blom 2018; Crinall 2019; Crinall and Vladimirova 2020; Cutter-Mackenzie-Knowles et al. 2019; Osborn et al. 2019; Vladimirova and Rautio 2018) understood through placebodies and spacetime wash through the busyness of doing education into ways of be(com)ing in the stillness of knowing as growing. Apart though still together. This co-blog post brings us to be, in the end, still. Can you also see the beam of light that lays across it? We choose lightness to inform a kind of education, that reduces and reuses our habits of resisting and retracting (elements of) ourselves from the earth; to re-turn ourselves to the earth (Barad 2014). When we look up, another post is arching radiant colour,

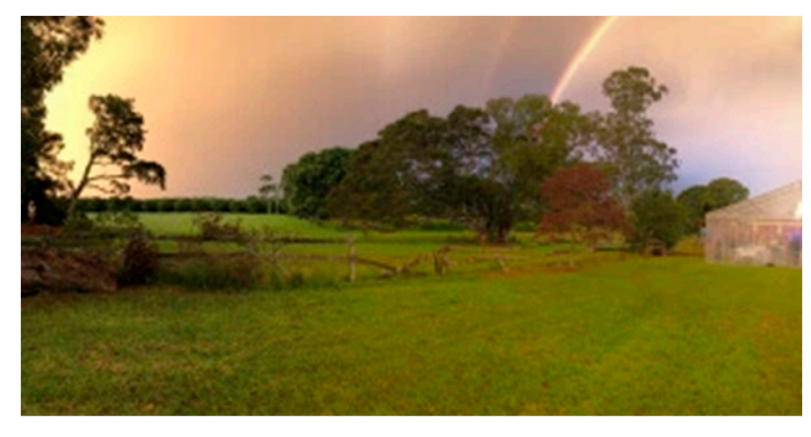

a giant double rainbow
landing in this tree
it perfectly looked like a
single
tree
but
it was
two being one
each side
looked to support the other
in an awkward
yet perfectly placed
symbiotic growing

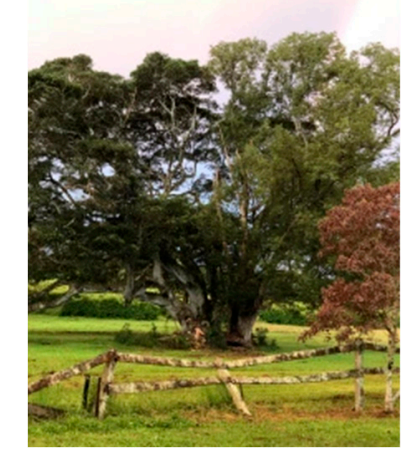

the support was a balance

and not a leaning on

it was leaning away 
and this is what

enabled the

growing together

quite the opposite

of what I have considered

and understood

growing to(gether to) be

Lea(r)ning away, togetherapart, this post invites us to grow in a way that might at first feel awkward. It supports a kin(d) of knowledge, from within, and beckons a reconceptualisation of community (Osborn et al. 2019). This idea of community does not need physical bodies to come together, enabling the growing together, but seeks to explore the potential of (be)coming together with a withinness. This extends thinking community beyond 'out-there' to also be 'in-here'; where the 'in-here' becomes what 'matters' (Blom 2018; Kahn and Hasbach 2013; Payne 1997).

For Barad (2014) the 'mattering' of existence is a 're-turning', as in 'turning it over, aerating life, in a multiplicity of processes like an earthworm is busy doing at work and play' (p. 168). Human as nature and nature as community diffracts ideas of what is with/in community into multitudes. While for Haraway (2016), 'critters interpenetrate one another, loop around and through one another, eat each another, get indigestion and partially digest and partially assimilate one another' (p. 58). Beyond the 'ecosystem destroying, human and animal labor-transforming, multispecies soul-mutilating, epidemic-friendly, corn-monocrop-promoting, cross-species heart-breakin' (Haraway 2016, p. 58), playfully, we note a univers-city-in-here; a place of learning and knowing, full of sparkling lights, that is all encompassing.

\section{Butterflies}

Metamorphosing

Cycle of contributions

Hibernates when left alone

Something beautiful unfolds.

Such synergy.

Our contributions have blossomed out of.

Difference and diffraction

Diffractive patterning

M-others as more than mothers

Womb-and

Entangled identity

Shift from roles to roles

Redefining mothering

Light is coming through

Play of ordering sense and meaning making

I love that order

Nature's messiness

Reconcepuatliaations

Of time 
Doesn't need to be long time

How much do we operate with the anxiety of body tension

At minds lead

Uncomfortable with mindfulness?

How about we change it to bodyfulness?

Listening to cells of the body

On eyes

We have blind spots

And light receptors in our akin

We don't know why yet

Shining a light in a child's eye in hyperactivity

Dull light

When they are focused

Calm

Shines lighter

As we get older

It dulls

The life that oozes and beams out of each object

In the two-slit experiment made famous by Bohr and Einstein (see Barad 2007, chp. 3), as a rainbow waves up from the screen it is demonstrated how particles can behave as both solid particles and as wavelengths of light. Light, as we know and understand it through Newtonian physics, has a source. So, how do we then understand the material bodies of us humans and those of trees as an emanating source of light? Now, reminded of the image of the actual shadow of a razor blade using monochromatic light as described by Barad (2007, p. 76), which describes diffractive patterning, it would then seem possible that we humans and trees are too emanating light in the same diffractive patterning. The relationality of matter, of trees and humans, oozing and beaming, is shown through the way we communicate through this light. With photoreceptors on our skin(s) (Cronin and Johnsen 2016) from where we emit and receive light in a (dis)continuous process.

The well-being of 'we', w.omen e.luding, are ...

working with 'past matter'

takes me to light

the way what we have was made so long ago

While you were writing this I was re-reading,

'oh yes, this sparkling light ray passing my gaze,'

Something beautiful unfolds from the light receptors we know in our skin, swiftly predatory tentacles of Drosera, morphing ocelli of Bocquila, and the seaweed press-cin of our unrecognisable unselves (Grosz 2005) or other selves on paper. Perhaps it's that when we divided individuality, a shift occurred from ' $i$ ' into a more-than duality travelling across space and time, body and place?

Beaming threads of diffraction are as a Chthulu spider's web of light rays passing our gaze. They map and unmap the garden undone. Sparkling light rays as bodies and more, were once only knowable as trees and humans to us, and are now different, lively, light. 
Light $n$ tangy

Treading lightly

A light touch

Light as a feather

Sensing with Haraway, objects here are light, alighting one kind of well-being for women and their people that shine from a light-growing blog, making kin not babies.

\section{Part Two: On Dark}

'Darkness is not mere absence,

But rather

an abundance'

(Barad 2014, p. 171)

\section{An Unkindness of Ravens}

In the blog,

ravens are everywhere here

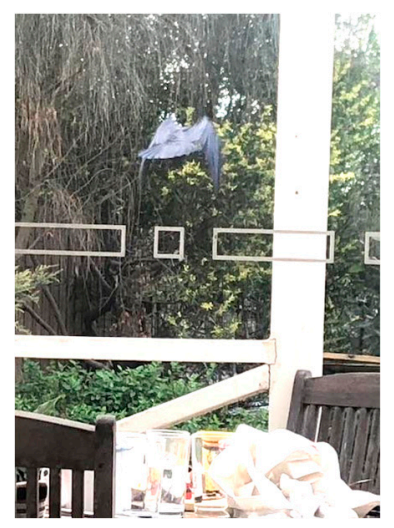

Raven came for lunch.

The way we writ we write together

reminds me of 'Raven',

The collective noun for a group of ravens is an 'unkindness'.

are we living if we are lead by a community of "should"?

Raven invites us on her wings into the in-between of dark light / night day to blur the binary stereotypes?

Today ravens appeared along the roadside

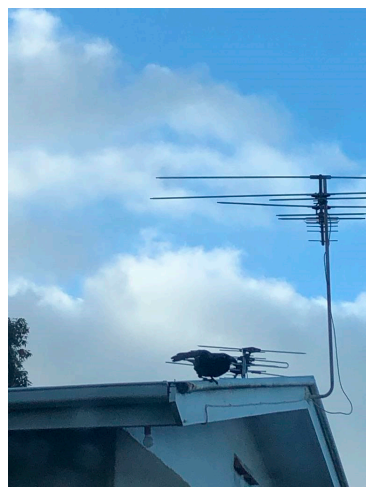


looking for cation

to turn dead back to life

as a 'pulse' every few kilometres, o noticed.

They weren't operating in time more than night / day rhythms though

for me

I felt another kind of tick tock that was more of a heartbeat that pulsed with inspiration each time I saw them

I'm back with our feathered wom(b)anliness.

in tension

in womb

in woman

In womb and in this book the crow comes to live with the family after the mother dies.

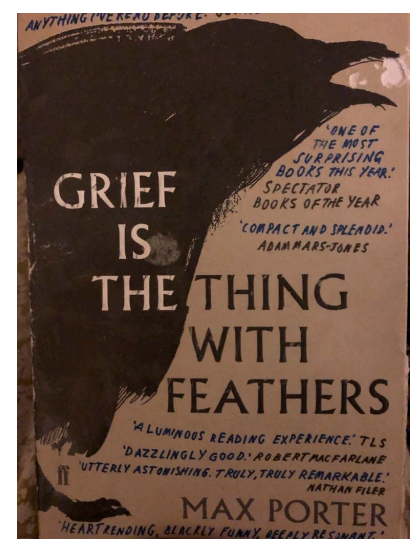

Leiove

What might be so unkind about a collective of ravens?

Haraway (2016) chose 'making kin not babies' as a slogan to motivate her worldly tending. This kinness, a multi-species living, for her is a worlding. Haraway (2016) argues that only with multi-species companionship might the cloudy trouble in which she invites us avidly to stay worlding, will our current epoch distill. And still?

Brings us to wonder, are human-humans living human-to-human lives, and living, unknowingly without kin? If so, this might be named an 'unkinness'?

Is it that here, in the post above, the blog has noted that the mother dies (Porter 2015)? Afterall, are we mothers though we do not write here of our children? In one way, we have died in the blogging/writing process. With Crinall and Vladimirova (2020), feminist new material philosophies of mothering became a material othering, a making other in the corresponding process, and it was sustaining (in) nature. It is not that the mother dies, but that the traditional stereotype of mother dies. The in-between-blog asked, if we do not write about mothering are we still mothers? And Haraway (2016), what kind of kin or world will mothers make if not babies?

Seaweed pressings are in the spaces

On white pages

And light dots

sea sparkle

Bouncing after singing 
Glass of water glistening

bathing an acorn leaf

in a drink of light

Electrons call into question the nature of self with Barad, they want to stay with the indeterminacy and to never settle

What is a mothering that never settles?

Barad's electron goes along

Emits a photon

And then

Horror

Absorbs it? (Barad 2012)

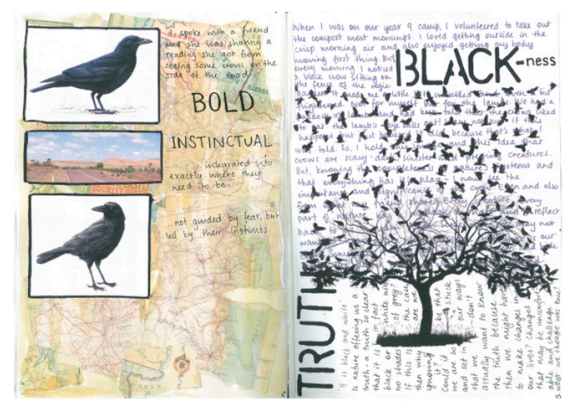

The raven seems the epitome of animal darkness flying in

This is not surprising to us right?

We are uncoding dark matter that gathers (in) here

Raven lands on the end of this co-blog post. What began with seaweed has reached the uncoding of dark matter that gathers in like a life flashing before an eye, this post travels through the garden at photon-like speed. Dressed in her bold, black feathers of truth, we wonder, what truth do you ask to share, raven? She is striking, a journal treasure. If the raven is calling for us to embrace the beauty of darkness in a life, then the $d$ in dark turns kin into kind. What is unsaid still matters, and enters (and is absorbed by) the light its own way.

Cosmic 'dark matter' is around $80 \%$ of the subatomic matter in the universe and remains unidentified (Powell 2013). It neither emits nor absorbs light. Cellular 'dark matter' comprises $97 \%$ of DNA that has long been thought to be 'unusable', until now. Its usefulness is coming to 'light' (Maxmen 2018). The 'un' returns, re-turns. How funny that an unkindness of ravens could be so kind to our play for worldly justice and reimagining (with) our community. With Grosz (2011) asking, we look to the unrecognisable, beyond identity, and we see we are working out of the dark matter now. That which cannot speak, cannot be said, still has something to give, or something to move, we might say.

While human-centred communities may find themselves allocating power to identity-formed Homo sapien sapiens, in human-to-human relations, new beings becoming enlighten how we are, differently—sparkling action potentials dancing (in) a community—into a new kind of communal living.

Reminds me of a favourite quote from Barad-

'The fact that things are disturbed when we measure them is not a startling new result of quantum physics 
— this point already follows from classical physics ...

When light bounces off a relatively large object,

the disturbance is negligible relative to the accuracy of the measurement.

That is,

it is often the case that any such disturbance is too small to notice.

(For example, we don't notice the furniture being rearranged in the room when we turn a light on in a dark room, although this is strictly the case)'

(Barad 2007, pp. 107-8)

The above blog post line takes flight with Barad's electron: Today ravens appeared along the roadside, looking for cation. Misspelling carrion so that it becomes a positively charged atom as a cation means there is an electron missing. When we began the blog, we engaged Barad on touch and heard her on electron perversity in a presentation recorded from a seabath of salty ionic water at Summer's end. An electron produces a photon (a particle of light) and later engulfs it (Barad 2012). Engulfing light returning matter to the unkind kind. To eat light might also be to eat various nutritious bodies following this articles musings and revelations. This is precisely how an ecological community maintains health. It is also how we might heal. There is a kindness to the unkindness, and an unkindness to the kindness. Perhaps, what is kind is not fixed, just as entities are not fixed?

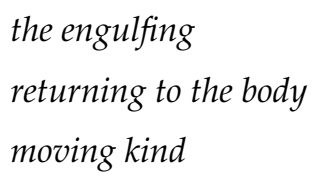

'Researcher: "So do you hear the plant?"

Raven: "Yeah, but you have to hear it through your heart."

Researcher: "I was going to ask where you hear it ... do you hear it in your heart?"

Raven: "Little words curl into your mind. You have to know that you're not

thinking'

(Blenkinsop and Piersol 2013, p. 54)

Raven is the pseudonym of a girl in a study by Blenkinsop and Piersol (2013). That she has the name Raven grows the recurrence of this bird in our meeting. When we noted the blog's raven arriving in the garden, mothering and becoming, it had not occurred to us that plant and raven were also one, always in communication, communicating 'with-in' a community, common-unity. Here where listening does not involve thinking or speaking, teaching or learning.

'If you're thinking then you're not really listening.

See I can't do it now when I'm talking ...

it's not 'speaking' it's more like energy or

signals. You don't hear it out loud. It's something that your mind and only your mind can understand because nature is that open to any language ... It's like the birds with those signals, like when you see a bird flapping up in the sky and a flock of birds how they all move at the same time, it's because they tell each other like through mental speaking'

(Blenkinsop and Piersol 2013, p. 54).

There are billions of ways to play out communication in communities on the feminist forest floor with Foucault, ravens, algae and moss. 
'Raven's descriptions of how she lives in and experiences the world shows a deep blurring of the lines between her 'self' and the 'other', "Sometimes I feel like Raven actually feels fall". "The season?" a researcher asks.

"Ya, the falling of the leaves, the coming of cold, the coming of weather as she stands there and thinks."

The staff member describes it as her "soaking" it all in" (Blenkinsop and Piersol 2013, p. 54)

Like for ravenplantchild, the blog captured one daughter also in bodily multispecies communication ...

Flooded with midday light

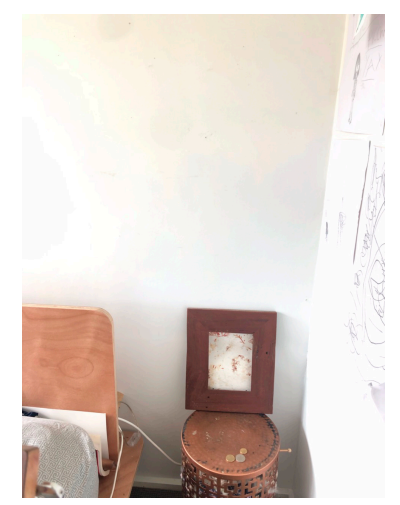

Wallaby in the dark

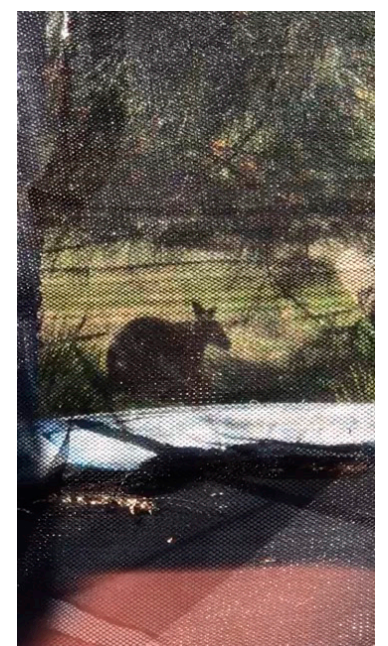

Sunlight and moss for you 


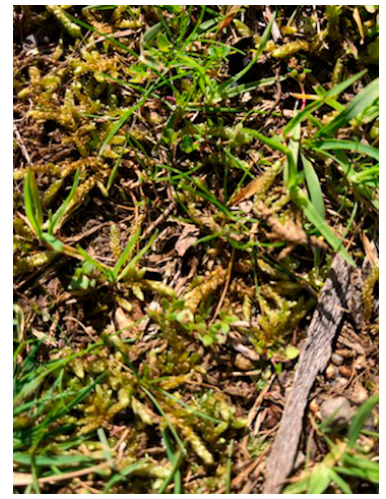

The quietly quietly of plants and light

Shhhh

Shhh and still said the girls

Respecting m-othering ${ }^{3}$

M-other has returned with babe in pouch

I thought to respond to you of it after two days ago the children and I were kicking the soccer ball in the backyard (where raven watched) and my daughter told me: If we take miss from here, the moss over there will die too. I know this moss grows in the shade, needs the shade, I just don't know how I know. Noone has told me.

Is the Moss Noone? In one place moss is misspelled as miss. Moss is often missed-camouflaged green patches that grow between the grass blades. We listen now. If our children are ever missed, we also hear them now. Shhh and still called daughter named after 'Grass Tree' at the approach of a wallaby and her kin in this blog post. The quiet gifted by moss and wallaby alike is not missed by our daughters. Perhaps we can all hear plants in the quietly quietly of a common union with our hearts of moving light and dark?

The sunlight has written us a love letter back:

Mothers,

talking yesterday morning

I thought a small child was running on the roof

It was raven telling truths of the day awake

The world articulates itself through the beat and best (the ones you can hear) of Raven's steps ... yes!

Love the sunlight-as-highlighter

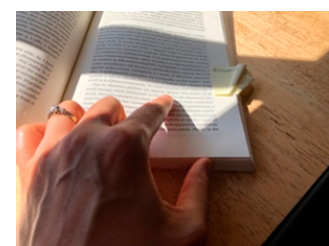

Uncoding dark matter that gathers (in) here

Out the kitchen window raven lands

3 This m-othering emerges via philosophies on mothering as sustaining in academia (Crinall and Vladimirova 2020). As if under a moss-bed, mothers-multiplicit and material others - are many while also one. 
I'm thinking about how you worked in the darkness and found the dark matter of our paper

A whoosh whoosh is the wings of raven as she flies off with my thought

She is picking paper from the swamp paperbark limb I dragged from

Lawson street after it fell

To love in our garden

For her nest

\section{Open-Ending}

Genealogy

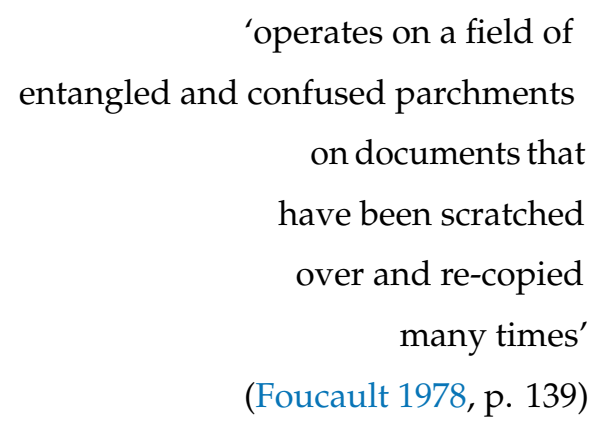

Together, we've been wandering through the co-blog. In an (un)kindness of ravings, we, kin with botanical positivism, have gazed outward into the insensible, and other life has poured in. In a genealogy of a stroking kind there are scratchings of a raven's beak, tickling grass, and the tiny reaching roots of shaded moss.

Right now, in relation as dark and light, in the abundance of the absence (Barad 2014, p. 171) we have a desire to make a difference to (one) another. Perhaps the light and dark of this paper are the diffractive ripples where the peak in the light moves into the valley of the dark in a forever process of unfurling, growing, responding, becoming. The dark of unsaid flies like the raven, a wallaby in the shadows, into the light of the sun or the unseen stars, to be said. An always moving, on an earth always (re)turning, an always becoming. Dark becomes light, unsaid becomes said, in its multiplicity of ways.

As communities, we seek to educate and alter for the better. Just as there is movement, there is also a stillness. As communities, we are still. (Still) coming into being, (still) said and unsaid, (still) still, and (still) abundant in the absence (see Murris 2018). Bringing warmth, they do not have an impact on an other in order to change the world because they are the world becoming solitude. With a light touch, communities might also be grown in the soil of a minimal impact, human-to-human and within more-than-just-human relations, and changing (in) the world by bringing lifefulness, perhaps provocatively, as a sparkling raven branch, with other life less.

I sneak a few words before bed

because

no coincidence

this too

is

a thing

i

have been

feeling

Into 


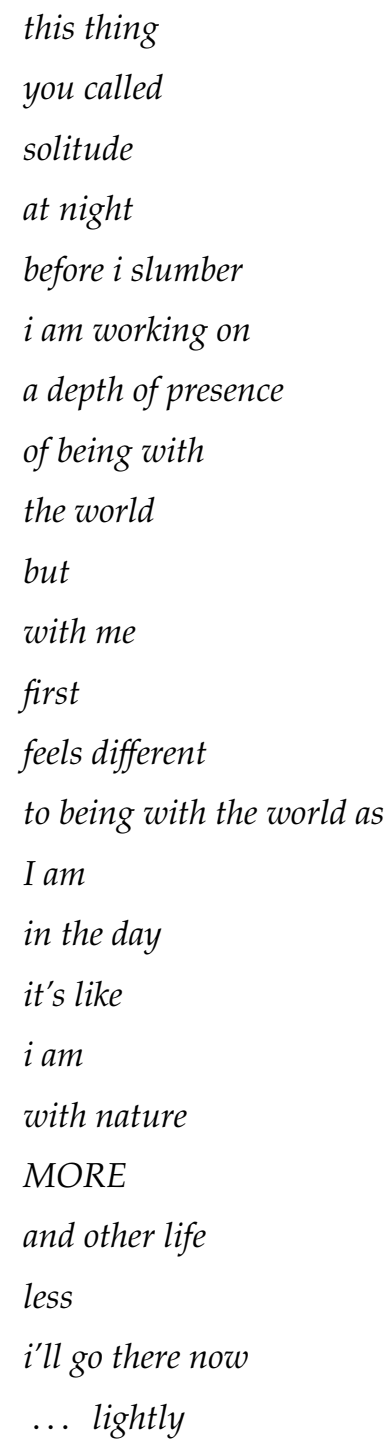

Upon exiting we re-turn to the entrance. The initial questions are signposted here reminding us, we have been strolling a re-imagining,

How does growing (with) plant-life, amongst what is 'said' and 'unsaid', matter (to) the world as it turns?

What counts as a meaningful world?

Having left with these questions as nutrients for our stroll, we do not attempt to offer an answer. We have queried 'community' in the context of sustenance and 'motherchildnaturehoods,' as sustainability education researchers, and we have noticed that stories of re-imagining human, animal, and plant living together are often marked with and in childhoods belonging to adults too.

On the notion of returning, we re-turn now to the Baradian concept of justice in relation to Earthly health and sustenance as another sign re-appears,

how might communities re-imagine life in relation to what is said and unsaid?

The Baradian ontological understanding of justice meets the world as always and already living diversely, and justly, for worldly health (Barad 2010) casting light across the darker, less seen. These inner, ever-present aspects of sustenance, are so often traditionally missed or considered less valuable by the Cartesian rational frame. By looking within communities for difference, diffractive patterning has returned us to a worldly justice where difference is seeable, sayable and sustaining. 
Perhaps our emergence came out of our oceanic worlds in one way and returns in another? As seaweeds picked up by the tide, washed out onto the shore, back in, and out again, in a breathing kind of nutrient cycle, we notice, gazing back through raven-dotted paths, we flew in dark feather disguise, and let go of seabeds where we had been long attached in the aquatic gardens that are ecologically understood as evolutionary first. As algae leaves the deeper sea to visit the light, it dwells in piles on our beaches, its intricate patterns are hidden, and occasionally seeable when washed open by waves on the shore. Perhaps writing this paper pressed out our patterns within, stilled us? Did we also shed our seaweed past and move away from understanding women as natural and more primitive (via Le Guin and Naimon 2018)?

We invite other unselves into the light. We see this paper leaving various new algae pressings to dry in the sunlight- they may preserve, fertilise, visually amaze or grow. Seen or unseen, still there.

Sitting on a bench now in rest and reflect, we remember the way we approached this research and its timely nature; never needed more urgently yet with no urgency. We observe this in the way children play-just as we did, with these words, our playful matterings. The Anthropocene calls for non-human nature kin and us to be nature-human and non-human-together though apart. We have attempted to respond to the need for research that is different, highlighting differences and sameness, through this paper. How research can be done in collaboration without boundaries or borders, in unity and sameness, from withinness, offers a new dynamism for research methodologies. Where bodyplaceblogging is a form of knowledge production under the post-qualitative umbrella, collaborating in the making offers us a vehicle to a radically new and different paradigm of knowledge production that is a dynamism of becomings rather than a linear telling of what is. The what in post-qualitative thinking is always already anew, diffracting through place and time.

This process of grappling with becoming undone as motherchildnaturehoods has been sustaining and now, we leave, radiating out. We take no conclusions as we exit.

Revelling in growing like breath, in and out-in many, radiant ways co-bodyplaceblogging as a methodology leafs this paper as a garden. Blog posts as seeds are left planted behind us, returned to sprout; this is in itself a community un-done-continuing their work undoing the idea of community being about people. The garden has been a way that we could metaphorically see planthumangardens everywhere. Having planted seeds for each other, tending our own gardens (and each other's gardens), some of those sprouts will go on to diffract through both of our lives in tangible ways (others returned as compost), allowing the ideas to grow bigger and stronger through our paper, others not sustained. Some breathed us both forth through the light that was shone as attention, thus the concept of light came to be. Just as blogs allowed that not everything needs to be responded to; this is the dark matter. The dark matter is allowed out without shame, which disappears in the respect dark matter have been given now, part of the living.

With the wor(l)ds in this garden paper, and there, we find the $l$ that was sprouted long ago, as you and we love, live, lieve, leaf, leave the garden.

Author Contributions: Methodology; data curation; writing_-original draft preparation, writing—review and editing; visualization: S.M.B. and S.C. All authors have read and agreed to the published version of the manuscript.

Funding: This research received no external funding.

Conflicts of Interest: The authors declare no conflict of interest.

\section{References}

Barad, Karen. 2007. Meeting the Universe Halfway. Durham and London: Duke University Press.

Barad, Karen. 2010. Quantum entanglements and hauntological relations. Derrida Today 3: 240-68. [CrossRef]

Barad, Karen. 2012. On touching-The inhuman that therefore I am. Differences 23: 206-23. [CrossRef]

Barad, Karen. 2014. Diffracting Diffraction: Cutting Together-Apart. Parallax 20: 168-87. [CrossRef]

Blenkinsop, Sean, and Laura Piersol. 2013. Listening to the literal: Orientations towards how nature communicates. Phenomenology \& Practice 7: 41-60. 
Blom, Simone Miranda. 2018. Conceptualizing Parent (ing) Childhoodnature Through Significant Life Experience. In Research Handbook on Childhoodnature: Assemblages of Childhood and Nature Research. Edited by Amy Cutter-Mackenzie-Knowles, Karen Malone and Elisabeth Barratt. Cham: Springer, pp. 1-26.

Brown, Shae L., Lisa Siegel, and Simone Miranda Blom. 2020. Entanglements of matter and meaning: The importance of the philosophy of Karen Barad for environmental education. Australian Journal of Environmental Education. [CrossRef]

Burin, Margaret. 2018. People from All over the World Are Sending Emails to Melbourne's Trees. ABC News. December 12. Available online: https://www.abc.net.au/news/2018-12-12/people-are-emailing-trees/10468964 (accessed on 18 December 2019).

Charteris, Jennifer, Sarah M. Crinall, Linette Etheredge, Eileen Honan, and Mirka Koro-Ljungberg. 2019. Writing, Haecceity, Data, and Maybe More. Qualitative Inquiry. [CrossRef]

Crinall, Sarah. 2016. Bodyplacetime: Painting and Blogging 'dirty messy' humannatured becomings. In Reimagining Sustainability in Precarious Times. Edited by Karen Malone, Son Truong and Tonia Gray. Singapore: Springer Press, pp. 95-114.

Crinall, Sarah. 2019. Sustaining Childhood Natures: The Art of Becoming with Water. Singapore: Springer Press.

Crinall, Sarah M., and Anna Vladimirova. 2020. Embodied motherly research: Re-birthing sustenance through the common (im)material. In (Re)birthing the Feminine in Academe: Creating Spaces of Motherhood in Patriarchal Contexts. Edited by Linda Henderson, Ali L. Black and Susanne Garvis. London: Palgrave Macmillan.

Cronin, Thomas W., and Sönke Johnsen. 2016. Extraocular, non-visual, and simple photoreceptors: An introduction to the symposium. Integrative and Comparative Biology 56: 758-63. [CrossRef] [PubMed]

Crutzen, Paul J., and Eugene F. Stroermer. 2000. The Anthropocene. Global Change Nerwsletter 41: 17.

Cutter-Mackenzie-Knowles, Amy, Karen Malone, and Elizabeth Barratt Hacking, eds. 2019. Research Handbook on Childhoodnature. Cham: Springer.

Deleuze, Gilles, and Felix Guattari. 1994. What Is Philosophy? New York: Columbia University Press.

Dickinson, Elizabeth. 2013. The misdiagnosis: Rethinking "nature-deficit disorder". Environmental Communication: A Journal of Nature and Culture 7: 315-35. [CrossRef]

Foucault, Michel. 1978. The History of Sexuality. Paris: Éditions Gallimard, vol. 1.

Gianoli, Ernesto, and Fernando Carrasco-Urra. 2014. Leaf Mimicry in a Climbing Plant Protects against Herbivory. Current Biology 24: 984-87. [CrossRef]

Grosz, Elizabeth. 1994. Volatile Bodies. Bloomington: Indiana University Press.

Grosz, Elizabeth. 2005. Time Travels. Durham and London: Duke University Press.

Grosz, Elizabeth. 2011. Becoming Undone. Durham \& London: Duke University Press.

Haraway, Donna. 2016. Staying with the Trouble: Making Kin in the Chthulucene. Durham and London: Duke University Press.

Kahn, Peter H., and Patricia H. Hasbach. 2013. The Rediscovery of the Wild. Hong Kong and Cambridge: MIT Press.

Le Guin, Ursula K., and David Naimon. 2018. Ursula Le Guin: Conversations on writing with David Naimon. Portland: Tin House Books.

MacLure, Maggie. 2013. Promiscuous feminists postscript. Journal of Qualitative Studies in Education 26: 625-28. [CrossRef]

Massumi, Brian. 1992. A User's Guide to Capitalism and Schizophrenia: Deviations from Deleuze and Guattari. Cambridge: MIT Press.

Maxmen, Amy. 2018. 'Dark matter' DNA influences brain development. Nature News. January 18. Available online: https://www.nature.com/articles/d41586-018-00920-x (accessed on 18 December 2019).

Murris, Karin. 2018. Posthuman Child and the Diffractive Teacher: Decolonizing the Nature/Culture Binary. In Research Handbook on Childhoodnature: Assemblages of Childhood and Nature Research. Edited by Amy Cutter-Mackenzie, Karen Malone and Elizabeth Barratt Hacking. Cham: Springer International Publishing, pp. 1-25.

Osborn, Maia, Simone Miranda Blom, Helen Widdop-Quinton, and Claudio Aguayo. 2019. De-imagining and Reinvigorating Learning with/in/as/for Community, Through Self, Other and Place. In Touchstones for Deterritorializing Socioecological Learning. Edited by Amy Cutter-Mackenzie-Knowles, Alexandra Lasczik, Judith Wilks, Marianne Logan, Angela Turner and Wendy Boyd. Cham: Palgrave Macmillan, pp. 189-230.

Payne, Phillip. 1997. Embodiment and Environmental Education. Environmental Education Research 3: 133-53. [CrossRef] 
Porter, Max. 2015. Grief Is the Thing with Feathers. London: Faber \& Faber.

Powell, Devin. 2013. In pursuit of dark matter. Proceedings for the National Academy of Sciences of the United States of America 110: 14113-15. [CrossRef] [PubMed]

Rautio, Pauliina. 2013. Children who carry stones in their pockets: On autotelic material practices in everyday life. Children's Geographies 11: 394-408. [CrossRef]

Somerville, Margaret. 1999. Body/Landscape Journals. Melbourne: Spinifex Press.

Somerville, Margaret. 2015. Writing the post-human 'I': the problem of the human subject in the more-than-human world. Paper presented at the American Education Research Association Meeting, Chicago, IL, USA, April $16-20$.

St. Pierre, Elizabeth A. 2014. A Brief and Personal History of Qualitative Research. Journal of Curriculum Theorizing 30: 1-19.

Taylor, Affrica. 2017. Beyond stewardship: common world pedagogies for the Anthropocene. Environmental Education Research 23: 1448-61. [CrossRef]

Trafton, Anne. 2016. Nanobionic spinach plants detect explosives. MIT News. October 31. Available online: http://news.mit.edu/2016/nanobionic-spinach-plants-detect-explosives-1031 (accessed on 18 December 2019).

Ulmer, Jasmine. 2017. Writing 'Data' Across Space, Time, and Matter. In Disrupting Data in Qualitative Inquiry: Entanglements with the Post-Critical and Post-Anthropocentric. Edited by Mirka Koro-Ljungberg, Marek Tesar and Teija Loytonen. New York: Peter Lang Publishing Inc., pp. 135-48.

Vladimirova, Anna, and Pauliina Rautio. 2018. Unplanning research with a curious practice methodology: Emergence of childrenforest in the context of Finland. In Research Handbook on Childhoodnature. Edited by Amy Cutter-Mackenzie, Karen Malone and Elizabeth Barratt Hacking. Cham: Springer, pp. 1-26.

(C) 2020 by the authors. Licensee MDPI, Basel, Switzerland. This article is an open access article distributed under the terms and conditions of the Creative Commons Attribution (CC BY) license (http://creativecommons.org/licenses/by/4.0/). 